\title{
Potassium Deprivation-Induced Apoptosis of Cerebellar Granule Neurons: A Sequential Requirement for New mRNA and Protein Synthesis, ICE-Like Protease Activity, and Reactive Oxygen Species
}

\author{
Jörg B. Schulz, Michael Weller, and Thomas Klockgether \\ Department of Neurology, University of Tübingen, D-72076 Tübingen, Germany
}

Potassium $\left(\mathrm{K}^{+}\right)$deprivation-induced apoptosis of cerebellar granule neurons requires new mRNA and protein synthesis. Using a fluorogenic substrate for interleukin- $1 \beta$ converting enzyme (ICE), we show that $\mathrm{K}^{+}$deprivation of cerebellar granule neurons induces cycloheximide-sensitive ICE-like protease activity. A peptide inhibitor of ICE-like protease activity, AcYVAD-chloromethylketone (Ac-YVAD-CMK), prevents $\mathrm{K}^{+}$ deprivation-induced apoptosis. Further, reactive oxygen species (ROS) are essential mediators of $\mathrm{K}^{+}$deprivation-induced apoptosis of cerebellar granule neurons because neuronal death is also blocked by superoxide dismutase, $\mathrm{N}$-acetyl-L- cysteine, and free radical spin traps. Using fluorescent assays, we show that ROS production after $\mathrm{K}^{+}$deprivation is blocked by actinomycin $D$, cycloheximide, and Ac-YVAD-CMK, suggesting that ROS act downstream of gene transcription, mRNA translation, and ICE activation. Taken together, we show that new mRNA and protein synthesis, activation of ICE-like proteases, and ROS production are sequential events in $\mathrm{K}^{+}$ deprivation-induced apoptosis of cerebellar granule neurons.

Key words: apoptosis; reactive oxygen species; interleukin-1 $\beta$ converting enzyme; ICE inhibition; cerebellar granule neurons; spin traps; superoxide dismutase
Programmed cell death refers to a spatially and temporally reproducible loss of cells that occurs during the normal development of the CNS. Neuronal programmed cell death is thought to serve the removal of neuronal precursors that fail to establish appropriate synaptic connections (Oppenheim, 1991; Johnson and Deckwerth, 1993). Morphologically, apoptosis underlies some, but not all, forms of developmental programmed cell death in the mammalian brain (Wood et al., 1993). Inappropriate apoptosis has been suggested to be involved in neuronal loss in various human neurodegenerative diseases, such as Alzheimer's disease (Loo et al., 1993), Huntington's disease (Portera-Cailliau et al., 1995), amyotrophic lateral sclerosis (Rabizadeh et al., 1995), and spinal muscular atrophy (Roy et al., 1995).

In vitro, mature cerebellar granule neurons deprived of depolarizing levels $(25 \mathrm{~mm})$ of extracellular potassium $\left(\mathrm{K}^{+}\right)$undergo apoptosis characterized by chromatin condensation, pyknosis, and nucleosomal size DNA fragmentation (D’Mello et al., 1993; Yan et al., 1994; Galli et al., 1995). Apoptosis of cerebellar granule neurons after $\mathrm{K}^{+}$deprivation is blocked by inhibitors of macromolecular synthesis, forskolin, and insulin-like growth factor.

The intracellular events that result in apoptosis are often genetically controlled by proapoptotic and antiapoptotic genes. The CED3 protein, which is required for cell death during the development of Caenorhabditis elegans, shows structural (Walker et al., 1994; Wilson et al., 1994) and functional (Miura et al., 1993; Yuan et al., 1993) homology to mammalian interleukin- $1 \beta$ converting enzyme (ICE). ICE is the first member of a family of cysteine

\footnotetext{
Received Feb. 8, 1996; revised April 18, 1996; accepted May 13, 1996.

We thank L. Dumitrescu and I. Müller for excellent technical assistance and Dr. P.-A. Löschmann for valuable discussions.

Correspondence should be addressed to Dr. Jörg B. Schulz, Department of Neurology, University of Tübingen, Hoppe-Seyler-Strasse 3, D-72076 Tübingen, Germany.

Copyright (C) 1996 Society for Neuroscience $0270-6474 / 96 / 164696-11 \$ 05.00 / 0$
}

proteases with the distinguishing feature of a near-absolute specificity for aspartate in the $S_{1}$ subsite (Thornberry et al., 1992). Subsequently, further proteases of the ICE familiy were identified as ICE-CED-3 homolog 1 (ICH-1/NEDD2), ICH-2, or CPP32/ YAMA (Miura et al., 1993; Kumar et al., 1994; Wang et al., 1994; Nicholson et al., 1995; Tewari et al., 1995).

The mammalian homolog of the $C$. elegans ced- 9 gene, which is a potent suppressor of cell death, is the $b c l-2$ gene. It has been suggested that $b c l-2$ regulates an antioxidant pathway to prevent apoptosis in lymphocytes (Hockenbery et al., 1993; Kane et al., 1993). Events that lead to oxidative stress, including exposure to $\beta$-amyloid (Loo et al., 1993; Behl et al., 1994) and transient ischemia (Héron et al., 1993; Rosenbaum et al., 1994; Li et al., 1995), may trigger neuronal apoptosis.

Reactive oxygen species (ROS) have been implicated as mediators of excitotoxic (Coyle and Puttfarcken, 1993; Schulz et al., 1995a,b) and apoptotic (Hockenbery et al., 1993; Kane et al., 1993; Greenlund et al., 1995; Rabizadeh et al., 1995) neuronal death. Overexpression of glutathione peroxidase inhibits apoptosis (Hockenbery et al., 1993), and the overexpression of copper-zinc superoxide dismutase (SOD) has been shown to inhibit apoptosis both in neural cell lines (Rabizadeh et al., 1995) and in primary neurons in culture (Greenlund et al., 1995). Free radicals may serve either as effectors of cell death, resulting in oxidative damage of DNA, lipids, and proteins, or as signaling molecules via redox-sensitive cellular factors such as c-jun or $\mathrm{NF} \kappa \mathrm{B}$ (Bredesen, 1995)

Here we report that new mRNA and protein synthesis, induction of ICE-like activity, and formation of ROS are sequential steps in $\mathrm{K}^{+}$deprivation-induced apoptosis of cerebellar granule neurons.

\section{MATERIALS AND METHODS}

Materials. Actinomycin D, cycloheximide, $N$-tert-butyl- $\alpha$-phenylnitrone (PBN), SOD, $N$-acetyl-L-cysteine, vitamin E, glutathione, catalase, 
cytosine- $\beta$-D-arabinofuranoside (Ara-C), phenylmethylsulfonyl fluoride (PMSF), $\quad N$-tosyl-L-lysyl chloromethylketone (TLCK), $N$-tosyl-Lphenylalanyl chloromethylketone (TPCK), E-64, aprotinin, pepstatin, poly-(L-lysine), and fluorescein diacetate were obtained from Sigma (St. Louis, MO). Biotinylated anti-rabbit IgG, control rabbit IgG, peroxidase, and alkaline phosphatase-conjugated anti-rabbit IgG were from Dakopatts (Glostrup, Denmark). RNase, avidin-alkaline phosphatase, fluorescein isothiocyanate-streptavidin, nitroblue tetrazolium chloride, and 5-bromo-4-chloro-3-indolyl phosphate were purchased from Boehringer Mannheim (Mannheim, Germany). Ac-YVAD-chloromethylketone (AcYVAD-CMK) and DABCYL-YVADAPV-EDANS were purchased from Bachem (Heidelberg, Germany). 2',7'-Dichlorodihydrofluorescein diacetate $\left(\mathrm{DCF}-\mathrm{H}_{2}\right)$ and dihydrorhodamine 123 were obtained from Molecular Probes (Groningen, Netherlands). ICE p10 (M20) rabbit polyclonal antibody raised against the p10 subunit of murine ICE was purchased from Santa Cruz Biotechnology (Heidelberg, Germany). p53antibody (AB-1) was obtained from Oncogene Science (Cambridge, MA).

Neuronal cultures. Cerebellar granule neurons were prepared from 8-d-old Sprague-Dawley rat pups (Interfauna, Tuttlingen, Germany) as described previously (Novelli et al., 1988; Marini and Paul, 1992; Weller et al., 1992, 1994c). Cells were dissociated from freshly dissected cerebella by mechanical disruption in the presence of trypsin and DNase and then plated in poly-L-lysine-precoated 35 or $100 \mathrm{~mm}$ culture plates (Nunc, Wiesbaden, Germany) or 24-well plates. Cells were seeded at a density of $2.1 \times 10^{5} \mathrm{cells} / \mathrm{cm}^{2}$ in basal modified Eagle's (BME) medium supplemented with $10 \%$ fetal calf serum, $2 \mathrm{mM}$ glutamine, and $20 \mu \mathrm{g} / \mathrm{ml}$ gentamycin. Cells maintained in depolarizing conditions were supplemented with $20 \mathrm{mM} \mathrm{KCl}$ to achieve a final concentration of $25 \mathrm{mM} \mathrm{K}^{+}$. Ara-C $(10 \mu \mathrm{M})$ was added to the culture medium after $24 \mathrm{hr}$ to arrest the growth of non-neuronal cells. Cultures were fed $5 \mathrm{~mm}$ D-glucose on day in vitro (DIV) 7. Cultures generated by this method have been characterized and shown to contain $>95 \%$ granule neurons (Nicoletti et al., 1986; M. Weller, unpublished data).

Treatment of cultures. All experiments were performed using cerebellar granule neurons at DIV 8. Neuronal viability was determined $24 \mathrm{hr}$ later. Culture medium was replaced with serum-free BME medium containing $5 \mathrm{~mm} \mathrm{KCl}$ and supplemented with glutamine and gentamycin as indicated above. Control cells were treated identically but maintained in serum-free BME medium supplemented with $25 \mathrm{mM} \mathrm{KCl}$ (final concentration). All drug solutions were sterilized by filtration and added in a volume of 2-20 $\mu 1$.

Morphometric analysis of cell viability. Neurons plated in $35 \mathrm{~mm}$ dishes were used for assessment of viability. Neuronal viability was assessed by the capability of cells to diesterify and retain fluorescein diacetate in their cytoplasm (Marini and Paul, 1992; Weller et al., 1992). Cells were washed with Locke's buffer (in mM): $154 \mathrm{NaCl}, 5.6 \mathrm{KCl}, 2.3 \mathrm{CaCl}_{2}, 1 \mathrm{MgCl}_{2}, 3.6$ $\mathrm{NaHCO}_{3}, 5 \mathrm{HEPES}$, and 20 glucose, incubated for $3 \mathrm{~min}$ at $37^{\circ} \mathrm{C}$ with 5 $\mu \mathrm{g} / \mathrm{ml}$ fluorescein diacetate dissolved in Locke's buffer, washed with Locke's buffer again, and then examined under ultraviolet light microscopy. Three randomly chosen fields from each dish were digitized by a blinded observer using a CCD camera connected to an image processor (MCID-IV, Imaging Research, St. Catharine's, Ontario, Canada). Images were averaged, filtered, and the total number of cells was estimated automatically by MCID-IV computer software. Parameters for the detection of granule neurons were the shape of cells (round) and the average diameter of the granule neurons $(7-12 \mu \mathrm{m})$. We confirmed the accuracy of computerized granule-neuron counting after switch to either high $\mathrm{K}^{+}$or low $\mathrm{K}^{+}$serum-free medium by comparing the counts of a blinded observer with the counts of the computer in several experiments. In high $\mathrm{K}^{+}$controls, 1500-1800 cerebellar neurons were counted per field. Viability is expressed as percentage of cerebellar granule neurons retaining fluorescein compared with high $\mathrm{K}^{+}$control cultures treated with the same drug.

Analysis of production of ROS. Cerebellar granule neurons were seeded in 24-well plates at a density of $2.1 \times 10^{5} \mathrm{cells} / \mathrm{cm}^{2}$ as described above. After the switch to medium containing low concentrations of $\mathrm{KCl}(5 \mathrm{mM})$ at DIV 8, the cultures were incubated for $30 \mathrm{~min}$ with $2 \mu \mathrm{g} / \mathrm{ml}$ dihydrorhodamine 123 or $1 \mu \mathrm{g} / \mathrm{ml}$ DCF- $\mathrm{H}_{2}$ at the time points indicated. Cells were washed with Locke's buffer and read on a CytoFluor 2350 plate reader (Millipore, Bedford, MA) at $485 \mathrm{~nm}$ excitation and $530 \mathrm{~nm}$ emission. Neurons that were not switched did not show any fluorescence and were used for background readings.

Fluorometric quantification of DNA fragmentation. For quantitative DNA fluorometry (Weller et al., 1994a,b), detached cerebellar granule neurons were harvested and pooled with the attached cells. All cells were lysed in $10 \mathrm{~mm}$ Tris-HCl, pH 7.5, $10 \mathrm{~mm}$ EDTA, and $0.2 \%$ Triton X-100 for $10 \mathrm{~min}$ on ice. Fragmented DNA was separated from nucleusattached DNA by high-speed centrifugation. After disruption of the pellets by brief sonication and RNase A digestion, fragmented and pelleted DNA was measured by ethidium bromide $(0.5 \mu \mathrm{g} / \mathrm{ml})$ fluorometry using $530 \mathrm{~nm}$ excitation and $620 \mathrm{~nm}$ emission wavelengths (CytoFluor 2350). The linear range was between 0.05 and $3 \mu \mathrm{g} / \mathrm{ml}$ DNA. Percent fragmentation was calculated by dividing fragmented DNA by the total sum of fragmented and pelleted DNA.

Detection of ICE and $p 53$ expression. Expression of ICE was detected by Western blot (Weller et al., 1994b, 1995). Cerebellar granule neurons were seeded on $100 \mathrm{~mm}$ dishes. Soluble protein was harvested from cells lysed for $15 \mathrm{~min}$ on ice in $50 \mathrm{~mm}$ Tris- $\mathrm{HCl}, \mathrm{pH} 8$, containing $120 \mathrm{~mm}$ $\mathrm{NaCl}, 0.5 \% \mathrm{NP}-40,2 \mu \mathrm{g} / \mathrm{ml}$ aprotinin, $100 \mu \mathrm{g} / \mathrm{ml}$ PMSF, $10 \mu \mathrm{g} / \mathrm{ml}$ leupeptin, $50 \mathrm{~mm}$ sodium fluoride, and $200 \mu \mathrm{M}$ sodium vanadate followed by high-speed centrifugation at $4^{\circ} \mathrm{C}$. Twenty micrograms protein per lane were separated by $15 \%$ sodium dodecyl sulfate-polyacrylamide gel electrophoresis and electroblotted to nitrocellulose. Immunodetection involved blocking for $1 \mathrm{hr}$ in $10 \mathrm{~mm}$ Tris- $\mathrm{HCl}, \mathrm{pH} 7.5$, containing $150 \mathrm{~mm}$ $\mathrm{NaCl}, 0.1 \%$ Tween $20,5 \%$ skim milk, and $2 \% \mathrm{BSA}$; incubation with antibodies to ICE p10 $(2 \mu \mathrm{g} / \mathrm{ml})$ or p53 $(2 \mu \mathrm{g} / \mathrm{ml})$ overnight at $4^{\circ} \mathrm{C}$; incubation with biotinylated anti-rabbit $\operatorname{IgG}(1: 20,000$ in $\mathrm{PBS} / 0.1 \%$ Tween 20), streptavidin-alkaline phosphatase $(1: 1,000)$, and nitroblue tetrazolium chloride $(0.41 \mathrm{~mm})$, and 5-bromo-4-chloro-3-indolyl phosphate $(0.38 \mathrm{~mm})$ in $200 \mathrm{~mm}$ Tris- $\mathrm{HCl}, \mathrm{pH} 9.5$, containing $10 \mathrm{~mm} \mathrm{MgCl}_{2}$ as substrate.

ICE activity. Cerebellar granule neurons were seeded in 24-well plates at a density of $2.1 \times 10^{5} \mathrm{cells} / \mathrm{cm}^{2}$ as described above. After the switch to medium containing low $(5 \mathrm{mM})$ or high $(25 \mathrm{mM})$ concentrations of $\mathrm{KCl}$ at DIV 8, cerebellar granule neurons were washed with Locke's buffer and made permeable by $0.03 \%$ digitonin for analysis of ICE-like protease activity at time points indicated. After $10 \mathrm{~min}$, the fluorogenic ICE substrate DABCYL-YVADAPV-EDANS $(20 \mu \mathrm{M})$ was added. Fluorescence was determined in $10 \mathrm{~min}$ intervals for $1 \mathrm{hr}$ using $360 \mathrm{~nm}$ excitation and $480 \mathrm{~nm}$ emission wavelengths (CytoFluor 2350) in the 24-well plates. The fluorometric intensity peaked at $20 \mathrm{~min}$. This time point was used for statistical analysis.

Statistics. Data are expressed as mean \pm SEM. Statistical significance was assessed by two-tailed Student's $t$ test (comparison of 2 groups) or one-way ANOVA followed by Scheffe's post hoc test (comparison of more than 2 groups). All experiments reported here represent at least three independent replications performed in triplicate.

\section{RESULTS \\ $\mathbf{K}^{+}$deprivation-induced apoptosis of cerebellar granule neurons}

Apoptosis of differentiated cerebellar granule neurons can be induced by lowering the extracellular $\mathrm{K}^{+}$concentration from 25 to 5 mm DIV 8 (D’Mello et al., 1993; Yan et al., 1994; Galli et al., 1995). Switch to low $\mathrm{K}^{+}$concentrations decreases viability of cerebellar granule neurons by $>50 \%$ when measured after $24 \mathrm{hr}$. As previously reported (Yan et al., 1994), exposure to the transcriptional inhibitor actinomycin D and the translational inhibitor cycloheximide at the time of $\mathrm{K}^{+}$deprivation protected against low $\mathrm{K}^{+}$-induced neuronal death as assessed by staining with fluorescein diacetate at $24 \mathrm{hr}$ (Fig. 1, Table 1). Quantitative DNA fluorometry showed that at this time point $28 \pm 3 \%$ of the total DNA was fragmented in neurons maintained in low $\mathrm{K}^{+}$versus $10 \pm 2 \%$ maintained in high $\mathrm{K}^{+}$medium. Treatment with actinomycin $\mathrm{D}$ and cycloheximide prevented DNA fragmentation induced by $\mathrm{K}^{+}$withdrawal (Table 1). Thus, new mRNA and protein synthesis appear to be required for $\mathrm{K}^{+}$deprivationinduced apoptosis of cerebellar granule neurons.

\section{p53 and ICE protein expression in low $\mathrm{K}^{+}$-induced apoptosis of cerebellar granule neurons}

We studied the role of two putative mediators of apoptotic cell death by Western blot. The tumor suppressor gene product $\mathrm{p} 53$ mediates apoptosis after DNA damage in certain cell types 

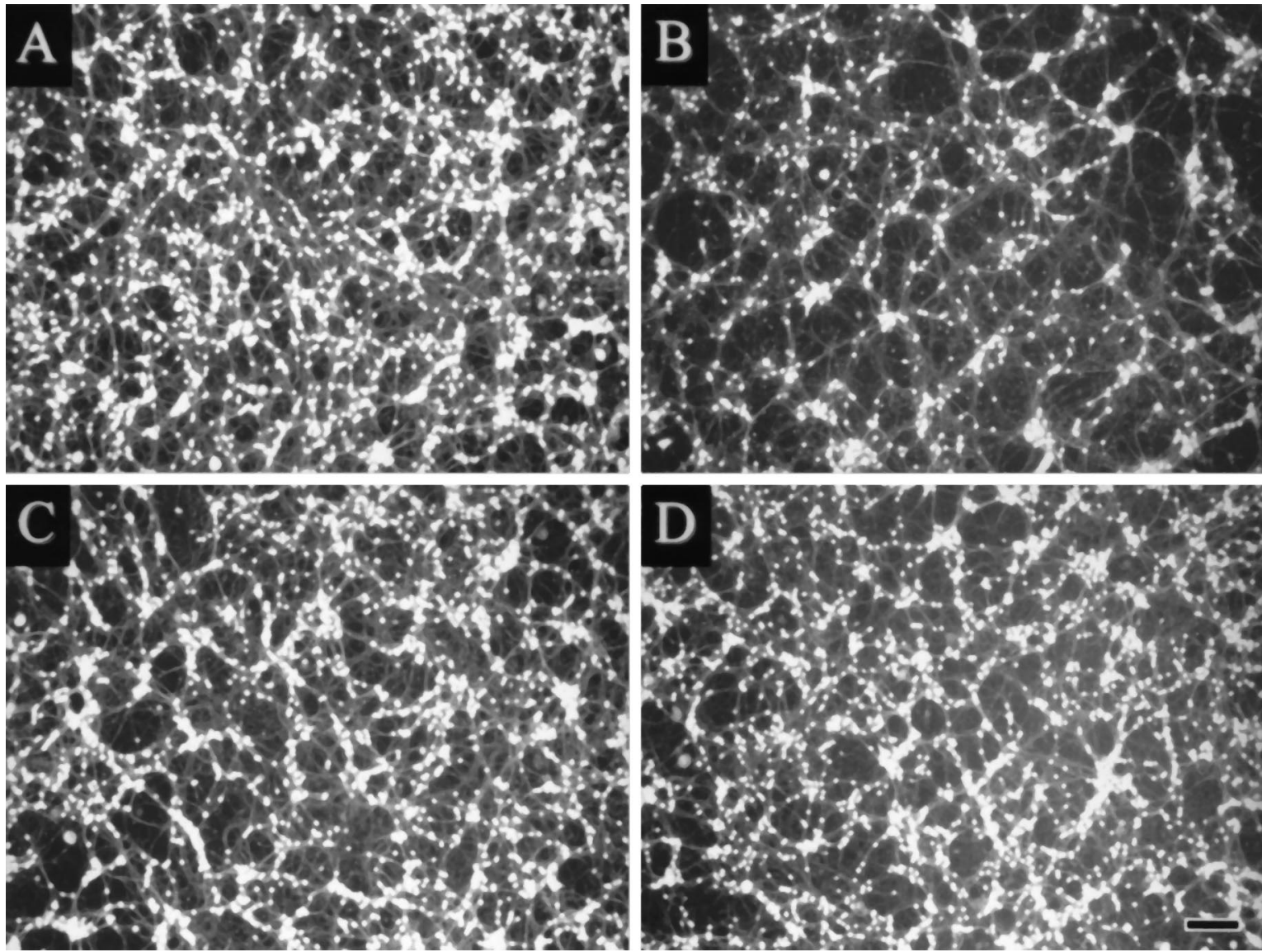

Figure 1. Cycloheximide and PBN prevent low $\mathrm{K}^{+}$deprivation-induced apoptosis. Neurons at DIV 8 were switched from high $\mathrm{K}^{+}(25 \mathrm{~mm})$ to low $\mathrm{K}^{+}$ $(5 \mathrm{~mm})$ serum-free culture medium and stained for viable cells with fluorescein diacetate $24 \mathrm{hr}$ later. Stained cells were visualized under ultraviolet illumination and digitized using a CCD camera. Culture $A$ was maintained in $25 \mathrm{~mm}$, cultures $B-D$ were kept at $5 \mathrm{~mm} \mathrm{~K}^{+}$. Low $\mathrm{K}^{+}$neurons were either untreated $(B)$ or treated with $10 \mu \mathrm{g} / \mathrm{ml}$ cycloheximide $(C)$ or $100 \mu \mathrm{M}$ PBN $(D)$. Scale bar, $50 \mu \mathrm{m}$.

Table 1. Effects of actinomycin $\mathrm{D}$ and cycloheximide on $\mathrm{K}^{+}$ deprivation-induced apoptosis of cerebellar granule neurons

\begin{tabular}{llll} 
Treatment & Medium & $\begin{array}{l}\text { Viability } \\
{[\%]}\end{array}$ & $\begin{array}{l}\text { DNA } \\
\text { fragmentation } \\
{[\%]}\end{array}$ \\
\hline No & high K & $100 \pm 3$ & $10 \pm 2$ \\
No & low K & $42 \pm 4$ & $28 \pm 3$ \\
Actinomycin D $(1 \mu \mathrm{g} / \mathrm{ml})$ & high K $^{+}$ & $100 \pm 6$ & $11 \pm 2$ \\
Actinomycin D $(1 \mu \mathrm{g} / \mathrm{ml})$ & low K & $89 \pm 5^{*}$ & $8 \pm 1^{*}$ \\
Cycloheximide $(10 \mu \mathrm{g} / \mathrm{ml})$ & high K $^{+}$ & $100 \pm 5$ & $8 \pm 2$ \\
Cycloheximide $(10 \mu \mathrm{g} / \mathrm{ml})$ & low K & $92 \pm 5^{*}$ & $9 \pm 1^{*}$
\end{tabular}

Cultures were switched to high $(25 \mathrm{~mm})$ or low $(5 \mathrm{~mm}) \mathrm{K}^{+}$serum-free medium, and actinomycin $\mathrm{D}$ or cycloheximide was added at concentrations indicated. Viability was determined by fluorescein diacetate staining at $24 \mathrm{hr}$. DNA fragmentation was determined by quantitative DNA fluorometry $24 \mathrm{hr}$ after switch to low or high $\mathrm{K}^{+}$ medium. ${ }^{*} p<0.001$ compared with untreated cerebellar granule neurons switched to low $\mathrm{K}^{+}$concentrations.

(Clarke et al., 1993; Lowe et al., 1993a,b). Although DNA breaks and DNA fragmentation are characteristic features of $\mathrm{K}^{+}$ deprivation-induced apoptosis of cerebellar granule neurons, we did not find any expression of p53 protein by Western blot up to $24 \mathrm{hr}$ after $\mathrm{K}^{+}$deprivation (Fig. 2A). T98G human malignant glioma cells, which express abundant mutant p53, were used as a positive control (Ullrich et al., 1992).

The cysteine protease ICE is the mammalian homolog of
CED-3, a C. elegans gene product required for cell death (Yuan et al., 1993). Although we detected the $45 \mathrm{kDa}$ ICE precursor (proICE) protein by immunoblot analysis with an antibody directed against the p10 subunit of murine ICE, we did not observe a band corresponding to the cleaved and active $10 \mathrm{kDa}$ subunit or a decrease in expression of the $45 \mathrm{kDa}$ proICE-protein, arguing against an activation of ICE (Fig. 2B).

\section{Inhibition of ICE-like proteases protects against apoptosis of cerebellar granule neurons}

To screen for other ICE-like proteases that might be involved in low $\mathrm{K}^{+}$-induced apoptosis of cerebellar granule neurons, we used Ac-YVAD-CMK, an irreversible and specific peptide inhibitor of ICE and ICE-like proteases (Thornberry et al., 1992; Lazebnik et al., 1994; Enari et al., 1995). Figure 3 shows that Ac-YVAD-CMK attenuated low $\mathrm{K}^{+}$-induced apoptosis of cerebellar granule neurons in a concentration-dependent manner when added at the time of $\mathrm{K}^{+}$withdrawal. Additional preincubation with Ac-YVADCMK for $1 \mathrm{hr}$ resulted in almost complete survival of cerebellar granule neurons as assessed $24 \mathrm{hr}$ after $\mathrm{K}^{+}$deprivation (Fig. 3A). The peptidic nature of the ICE inhibitor limits cell penetration, which may explain the requirement of micromolar concentrations and preincubation with this agent for complete inhibition of apoptosis. Treatment with Ac-YVAD-CMK had no effect on granule neurons maintained at high $\mathrm{K}^{+}$concentrations, indicating that the ICE inhibitor is not toxic at concentrations tested. The cysteine protease inhibitors E-64 and leupeptin, the aspartic pro- 
Table 2. Effects of protease inhibitors on $\mathrm{K}^{+}$deprivation-induced apoptosis of cerebellar granule neurons

\begin{tabular}{|c|c|c|c|c|c|c|}
\hline \multirow[b]{2}{*}{ Inhibitor } & \multirow[b]{2}{*}{ Specificity } & \multirow[b]{2}{*}{ Medium } & \multicolumn{4}{|c|}{ Viability [\%] normalized to high $\mathrm{K}^{+}(25 \mathrm{~mm})$} \\
\hline & & & No treatment & {$[1 \mu \mathrm{M}]$} & {$[10 \mu \mathrm{M}]$} & {$[100 \mu \mathrm{M}]$} \\
\hline TPCK & Chymotrypsin & high $\mathrm{K}^{+}$ & $100 \pm 5$ & $93 \pm 5$ & $20 \pm 8$ & 0 \\
\hline \multirow[t]{2}{*}{ TLCK } & Trypsin & high $\mathrm{K}^{+}$ & $100 \pm 5$ & $95 \pm 7$ & $83 \pm 4$ & 0 \\
\hline & & low $\mathrm{K}^{+}$ & $59 \pm 6$ & $52 \pm 4$ & $48 \pm 5$ & 0 \\
\hline PMSF & Serine protease & high $\mathrm{K}^{+}$ & $100 \pm 8$ & n.t. & $101 \pm 7$ & $70 \pm 1$ \\
\hline & & low $\mathrm{K}^{+}$ & $59 \pm 6$ & n.t. & $61 \pm 7$ & $57 \pm 5$ \\
\hline \multirow[t]{2}{*}{ Leupeptin } & Cysteine proteases & high $\mathrm{K}^{+}$ & $100 \pm 5$ & n.t. & $99 \pm 3$ & $107 \pm 7$ \\
\hline & & low $\mathrm{K}^{+}$ & $47 \pm 5$ & n.t. & $60 \pm 4$ & $56 \pm 5$ \\
\hline \multirow[t]{2}{*}{ Pepstatin } & Aspartic proteases & high $\mathrm{K}^{+}$ & $100 \pm 5$ & n.t. & $99 \pm 4$ & $66 \pm 7$ \\
\hline & & low $\mathrm{K}^{+}$ & $59 \pm 6$ & n.t. & $52 \pm 6$ & $33 \pm 2$ \\
\hline
\end{tabular}

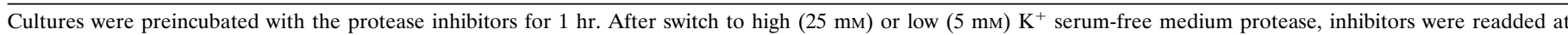

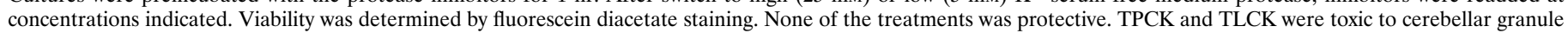
cells in low $\mathrm{K}^{+}$and high $\mathrm{K}^{+}$medium at concentrations of 10 and $100 \mu \mathrm{M}$, respectively. n.t., Not tested.

tease inhibitor pepstatin, the serine protease inhibitor PMSF, the chymotrypsin inhibitor TPCK, and the trypsin inhibitor TLCK had no effect on $\mathrm{K}^{+}$deprivation-induced apoptosis at concentrations tolerated by the granule neurons (Table 2).

To confirm that $\mathrm{K}^{+}$deprivation induces ICE-like proteases,
ICE-like proteolytic activity was measured using the fluorogenic ICE substrate 4-(4-dimethylaminophenylazo)benzoylYVADAPVU-5-[(2-aminoethyl)amino]-naphthalene-1-sulfonic acid (DABCYL-YVADAPV-EDANS), which contains the cleavage site of the ICE-like enzymes (Pennington and Thornberry, 1994).

A

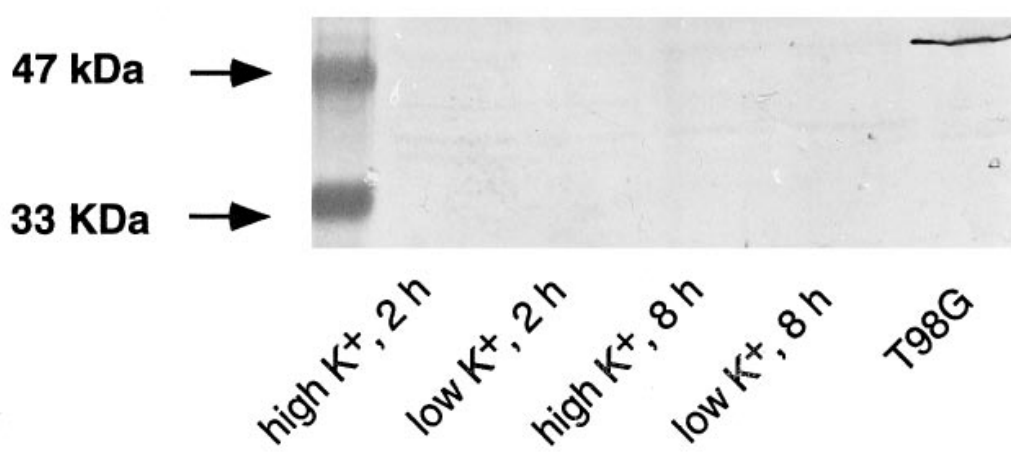

B
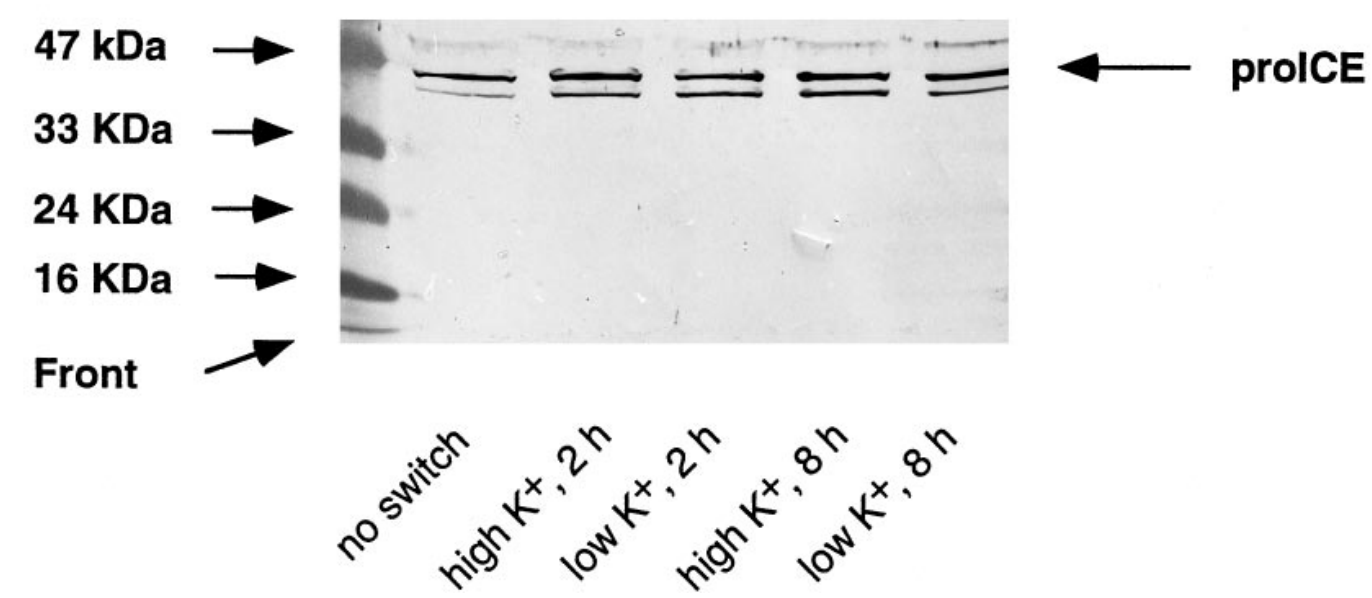

Figure 2. $\mathrm{p} 53$ and ICE protein expression of cerebellar granule neurons during $\mathrm{K}^{+}$deprivation-induced apoptosis. Protein expression was determined at the time points indicated after switch to serum-free medium with high $(25 \mathrm{mM})$ or low $(5 \mathrm{~mm})$ concentrations of $\mathrm{K}^{+}$. $A$, p53 protein expression was not detected in cerebellar granule neurons after switch to low or high $\mathrm{K}^{+}$medium. T98G human malignant glioma cells served as a positive control. $B$, The $45 \mathrm{kDa}$ ICE precursor protein, but not the cleaved $10 \mathrm{kDa}$ protein, was detected in cerebellar granule neurons. 
A

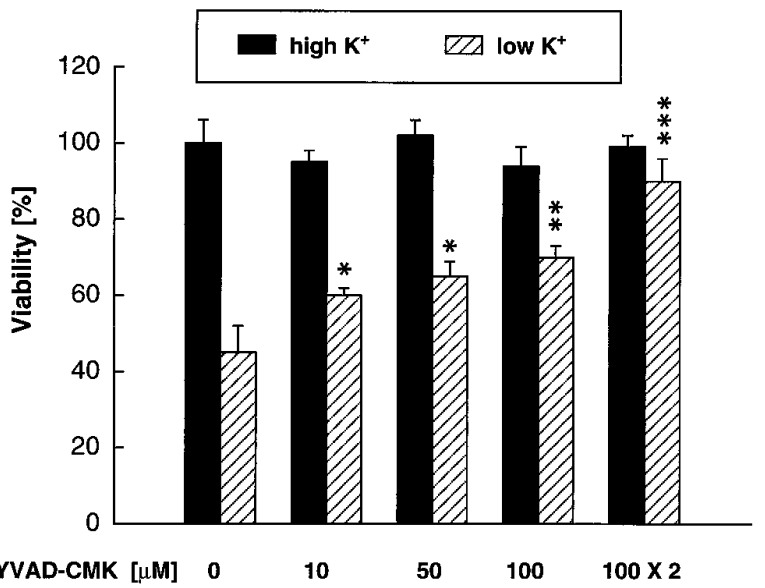

$\begin{array}{llllll}\text { Ac-YVAD-CMK }[\mu M] & 0 & 10 & 50 & 100 & 100 \times 2\end{array}$

B

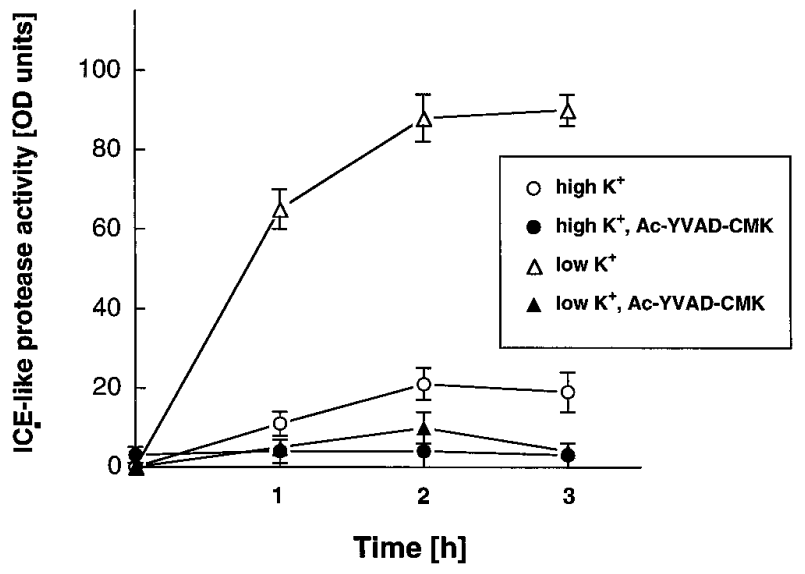

Figure 3. The role of ICE-like proteases in $\mathrm{K}^{+}$deprivation-induced apoptosis. $A$, Inhibition of ICE-like protease activity abrogates $\mathrm{K}^{+}$ deprivation-induced apoptosis of cerebellar granule neurons. Apoptosis was induced by $\mathrm{K}^{+}$deprivation. Neurons maintained in high $\mathrm{K}^{+}$medium were used to control for possible toxic effects of the ICE inhibitor. Neuronal viability was assessed by fluorescein diacetate staining and interactive counting by an image analysis system. The ICE inhibitor tetrapeptide Ac-YVAD-CMK was added at the time point of medium switch. Additional preincubation with Ac-YVAD-CMK for $1 \mathrm{hr}$ before switch showed the best protection $(100 \mu \mathrm{M} \times 2)$. ${ }^{* * *} p<0.001$, ${ }^{* *} p<0.01$, ${ }^{*} p<0.05$ compared with untreated granule neurons maintained at low $\mathrm{K}^{+} . B$, ICE-like protease activity is induced after $\mathrm{K}^{+}$deprivation. ICE-like protease activity was measured with the fluorogenic ICE substrate DABCYL-YVADAPV-EDANS in the absence or presence of AcYVAD-CMK in low or high $\mathrm{K}^{+}$medium at defined time points after medium switch.

Measurements at 1, 2, and $3 \mathrm{hr}$ after switch to low $\mathrm{K}^{+}$confirmed an increase in ICE-like protease activity that was blocked by Ac-YVADCMK (Fig. 3B).

\section{Antioxidants and free radical spin traps block $\mathrm{K}^{+}$ deprivation-induced apoptosis of cerebellar granule neurons}

ROS have been implicated as important effector molecules in apoptotic cell death (Hockenbery et al., 1993; Kane et al., 1993; Zamzami et al., 1995). Therefore, we studied the effects of the antioxidants SOD, $N$-acetyl-L-cysteine, catalase, glutathione, vitamin E, and PBN on apoptosis of cerebellar granule neurons induced by $\mathrm{K}^{+}$deprivation at DIV 8 . PBN is a free radical spin
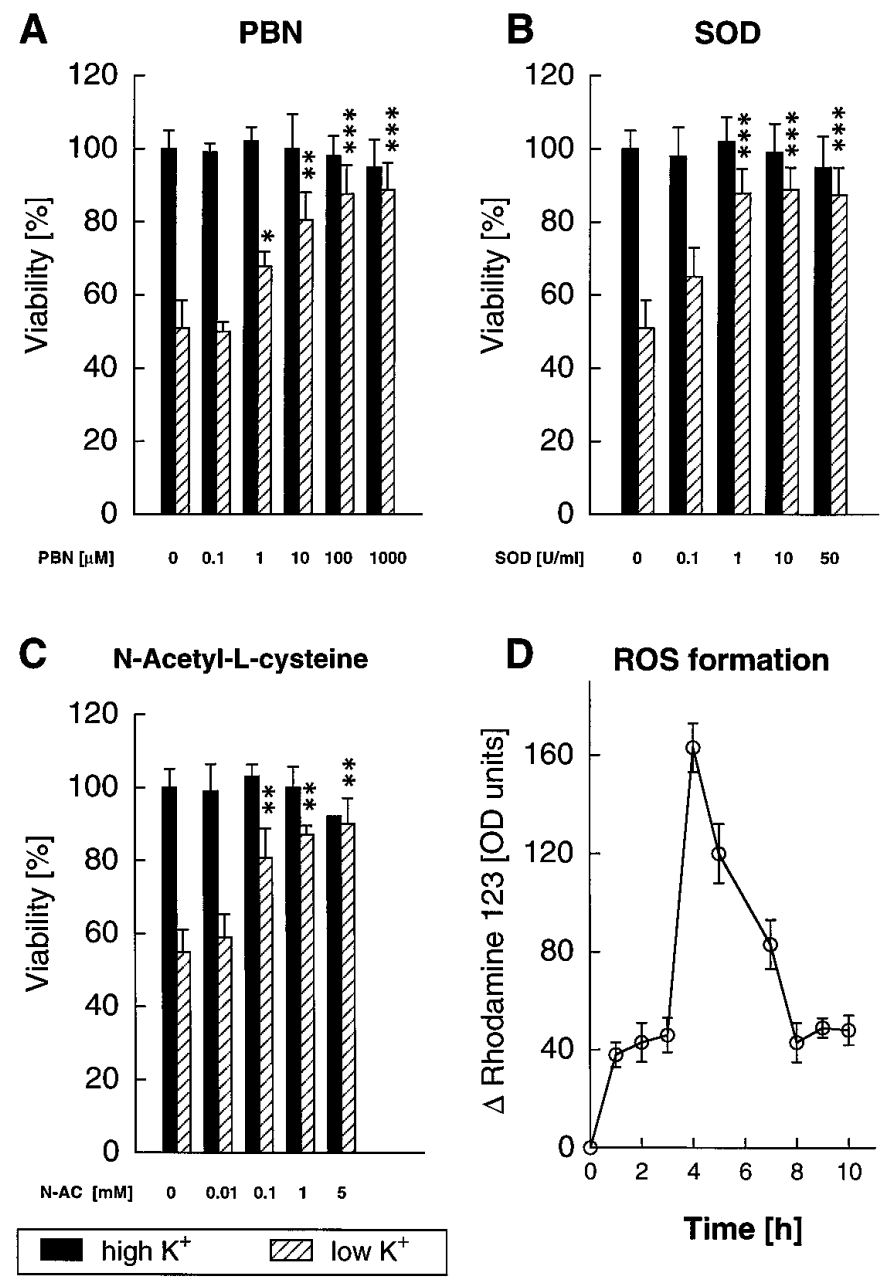

Figure 4. $\mathrm{K}^{+}$deprivation-induced apoptosis requires ROS formation. Effects of treatment with $N$-tert-butyl- $\alpha$-phenylnitrone $(P B N)(A)$, superoxide dismutase $(S O D)(B)$, and $N$-acetyl-L-cysteine $(C)$. Neuronal viability was assessed by fluorescein diacetate staining and interactive counting by an image analysis system at $24 \mathrm{hr}$ after switching to low $\mathrm{K}^{+} .{ }^{* * *} p<$ $0.001,{ }^{*} p<0.01,{ }^{*} p<0.05$ compared with untreated cells switched to low $\mathrm{K}^{+} . D$ shows the time course of ROS production as detected by dihydrorhodamine 123 fluorescence. Because the switch to serum-free high $\mathrm{K}^{+}$ medium led to a minor increase in the fluorescence of both dyes compared with nonswitched controls, the difference in fluorescence between high $\mathrm{K}^{+}$- and low $\mathrm{K}^{+}$-treated cultures at every time point is given.

trap that reacts with free radicals to form stable adducts and can therefore serve as a free radical scavenger (Knecht and Mason, 1993; Schulz et al., 1995a). Exposure to PBN, SOD, and $N$-acetylL-cysteine concentration dependently inhibited cerebellar granule neuron death at $24 \mathrm{hr}$ (Fig. 4). Treatment with glutathione (100 $\mu \mathrm{M}: 88 \pm 5 \%$ vs $51 \pm 4 \%$ viability normalized to $25 \mathrm{mM} \mathrm{K}^{+} ; p<$ $0.01)$, vitamin E $(1 \mathrm{mg} / \mathrm{ml}: 78 \pm 6 \%$ vs $51 \pm 4 \% ; p<0.05)$, and catalase $(1000 \mathrm{U} / \mathrm{ml}: 72 \pm 5 \%$ vs $51 \pm 4 \% ; p<0.05)$ was also effective.

To confirm the generation of ROS directly and to follow the time course of ROS production, we used the oxidation-sensitive indicators dihydrorhodamine 123 and $\mathrm{DCF}-\mathrm{H}_{2}$. These lipophilic nonfluorescent indicators are easily deacetylated to their active forms after penetrating cells. They are oxidized by ROS to the fluorescent dyes rhodamine 123 and DCF, respectively. Because the fluorescent derivative rhodamine 123 is positively charged, it moves to the inside-negative mitochondrial environment (John- 
son et al., 1980). Staining with dihydrorhodamine 123 showed a gradual increase in fluorescence over time with a maximum at $4 \mathrm{hr}$ after $\mathrm{K}^{+}$deprivation and a slow decline thereafter (Fig. 4D). A similar time course of ROS production with a maximum at $4 \mathrm{hr}$ was obtained by staining with $\mathrm{DCF}-\mathrm{H}_{2}$ with the exception of an additional minor peak of DCF fluorescence at $1 \mathrm{hr}$.

Four hours after switch to low $\mathrm{K}^{+}$concentrations, we used confocal laser microscopy to confirm that ROS were generated intracellularly. Culture dishes were loaded with $4 \mu \mathrm{g} / \mathrm{ml}$ dihydrorhodamine 123 or $2 \mu \mathrm{g} / \mathrm{ml} \mathrm{DCF}-\mathrm{H}_{2}$ for $30 \mathrm{~min}$. After this incubation period, cellular fluorescence was imaged using a laser scanning confocal microscope at $485 \mathrm{~nm}$ excitation and $530 \mathrm{~nm}$ emission. For both dyes, fluorescence was strictly localized within cerebellar granule neurons (data not shown).

\section{DNA fragmentation and survival}

Fragmentation of nuclear DNA is a typical feature of apoptosis. A $17 \%$ increase of DNA fragmentation was observed at $24 \mathrm{hr}$ after switch to low $\mathrm{K}^{+}$medium compared with switch to high $\mathrm{K}^{+}$ medium (Fig. $5 A$ ). This increase was blocked by treatment with actinomycin D and cycloheximide, but not with PBN or AcYVAD-CMK. Yet, these drugs greatly enhanced neuronal viability as assessed by staining with fluorescein diacetate at the same time point. To confirm that PBN- and Ac-YVAD-CMK-mediated rescue of staining with fluorescein diacetate at $24 \mathrm{hr}$ after $\mathrm{K}^{+}$ deprivation truly reflected survival compared with untreated neurons, and that DNA fragmentation at $24 \mathrm{hr}$ did not inevitably predict neuronal death, cerebellar granule neurons were switched back to their initial conditioned medium $24 \mathrm{hr}$ after $\mathrm{K}^{+}$deprivation and cultured for another $48 \mathrm{hr}$. According to staining with fluorescein diacetate, reexposure to the original medium arrested the process of neuronal apoptosis induced by $\mathrm{K}^{+}$deprivation in that neuronal counts exceeded $35 \%$ in cultures switched back to high $\mathrm{K}^{+}$medium, whereas $<10 \%$ of the neurons survived $72 \mathrm{hr}$ culture in low $\mathrm{K}^{+}$medium (Fig. 5B). Further, staining with fluorescein diacetate at $72 \mathrm{hr}$ confirmed near-complete rescue from $\mathrm{K}^{+}$deprivation-induced apoptosis in neurons exposed to either cycloheximide, ICE-inhibitor, or $\mathrm{PBN}$ during $\mathrm{K}^{+}$deprivation from 0 to $24 \mathrm{hr}$. At $72 \mathrm{hr}$, DNA fragmentation in neurons treated with PBN and Ac-YVAD-CMK was reduced compared with measurements at the end of $\mathrm{K}^{+}$deprivation (24 hr). In fact, DNA fragmentation of PBN- or Ac-YVAD-CMK-treated neurons at 72 hr was not different from that of cycloheximide-treated neurons (Fig. 5A), suggesting that DNA repair takes place during high $\mathrm{K}^{+}$-mediated rescue of the neurons between 24 and $72 \mathrm{hr}$. Because there was no decrease in total DNA harvests between 24 and $72 \mathrm{hr}$, a selective loss of fragmented DNA into the culture medium is unlikely to account for the decrease of DNA fragmentation.

\section{Sequential mechanisms of apoptosis in cerebellar granule neurons}

To characterize the sequential mechanisms during $\mathrm{K}^{+}$ deprivation-induced apoptosis of cerebellar granule neurons, we determined the point of commitment to death as the latest time at which neurons can be rescued after switch to low $\mathrm{K}^{+}(5 \mathrm{~mm})$ by addition of a given survival agent (Fig. 6). Neurons were shifted to low $\mathrm{K}^{+}$medium and, at different time points, actinomycin $\mathrm{D}$, cycloheximide, or PBN was added to the culture medium. At 24 $\mathrm{hr}$, neuronal survival was evaluated by fluorescein diacetate staining. Neurons were rescued by addition of PBN up to $3 \mathrm{hr}$ after the initial switch to low $\mathrm{K}^{+}$. The therapeutic window for the transcrip-
A $24 \mathrm{~h}$

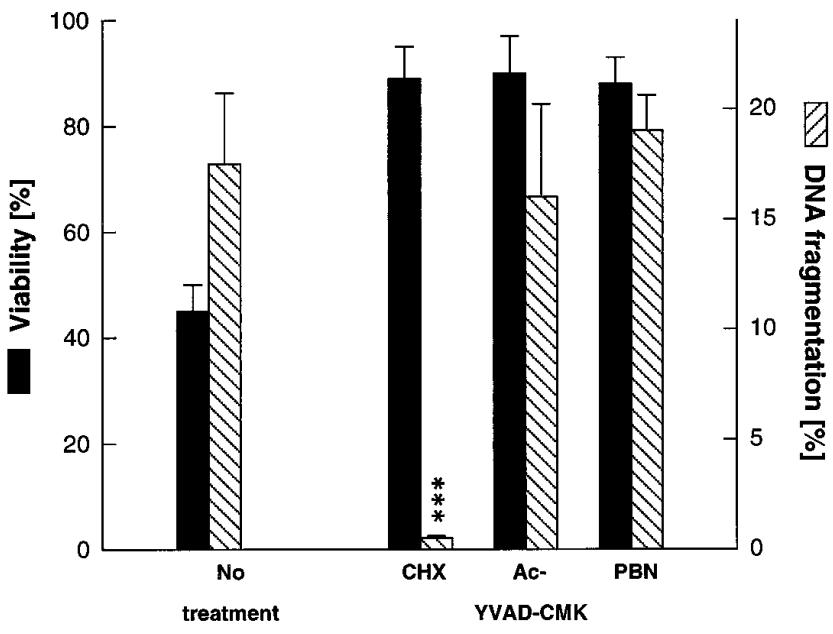

B

$72 \mathrm{~h}$

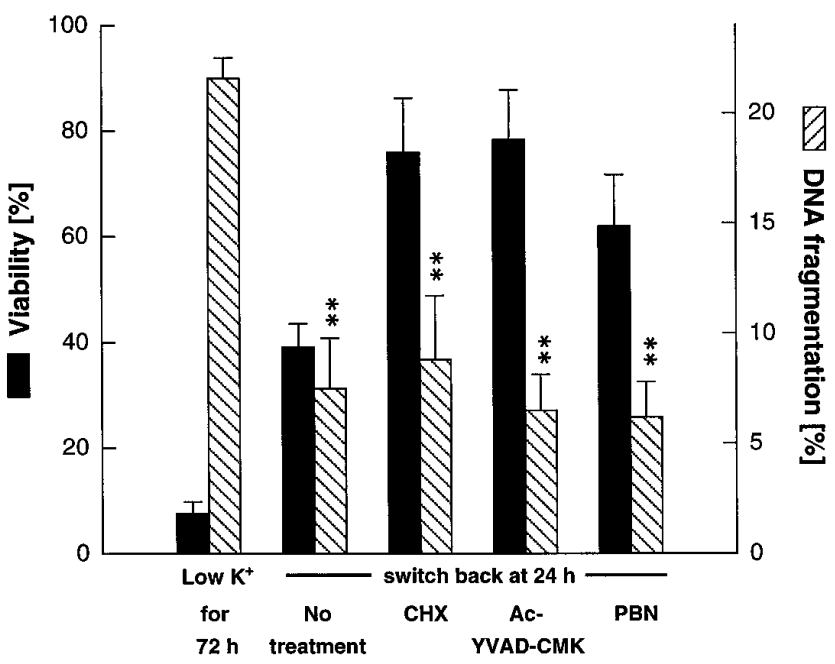

Figure 5. DNA fragmentation and survival after $\mathrm{K}^{+}$deprivation. Cell viability and specific DNA fragmentation were measured $24(A)$ and 72 $(B) \mathrm{hr}$ after switch to low $\mathrm{K}^{+}$medium. Specific DNA fragmentation was calculated by subtracting baseline DNA fragmentation before calculating ratios of fragmented versus pelleted DNA in experimental samples. In these experiments, baseline DNA fragmentation never exceeded $9 \%$ in cells switched to high $\mathrm{K}^{+}$concentrations. $A$, Treatment with cycloheximide $(C H X), A c-Y V A D-C M K$, and $P B N$ greatly enhanced neuronal viability at $24 \mathrm{hr}$ after $\mathrm{K}^{+}$withdrawal as assessed by staining with fluorescein diacetate. However, only treatment with cycloheximide prevented DNA fragmentation $(* * * p<0.001)$. $B$, When cerebellar granule neurons were switched back to their initial conditioned medium $24 \mathrm{hr}$ after $\mathrm{K}^{+}$deprivation and cultured for another $48 \mathrm{hr}$, significantly more neurons remained viable compared with neurons continuously maintained in low $\mathrm{K}^{+}$ medium for $72 \mathrm{hr}(p<0.01)$. Furthermore, treatment with cycloheximide, ICE inhibitor, and PBN was protective. After switch back to preconditioned high $\mathrm{K}^{+}$medium, DNA fragmentation was markedly reduced in treated and untreated cells compared with neurons at the end of $\mathrm{K}^{+}$ deprivation $(24 \mathrm{hr})$ and with neurons maintained in low $\mathrm{K}^{+}$for $72 \mathrm{hr}$ $\left({ }^{* *} p<0.01\right)$.

tional and translational inhibitors actinomycin D and cycloheximide, respectively, was shorter. To obtain a significant protection, actinomycin $\mathrm{D}$ had to be added within $40 \mathrm{~min}$ and cycloheximide within $60 \mathrm{~min}$ after $\mathrm{K}^{+}$deprivation. These results suggest that, 


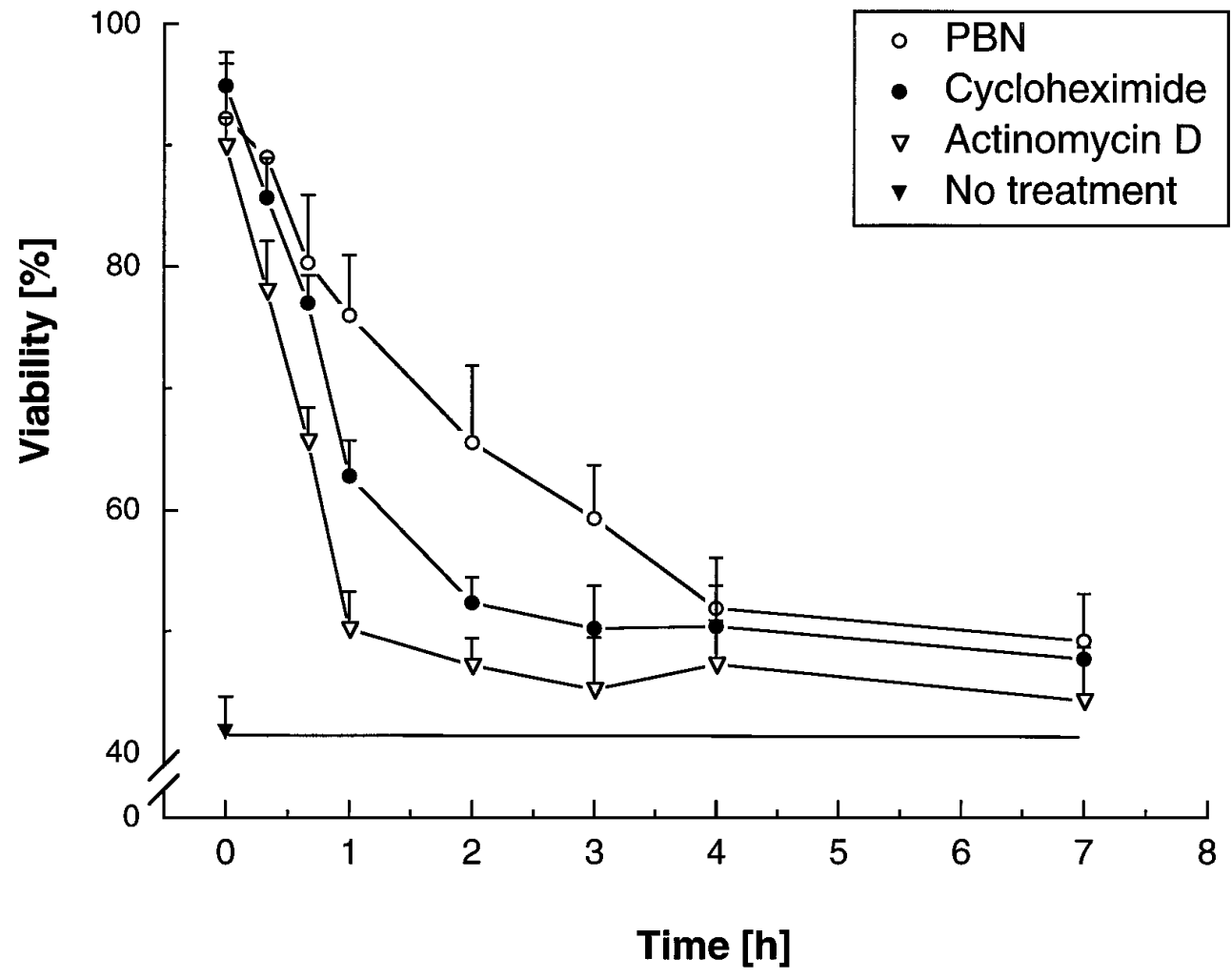

within $1 \mathrm{hr}$, most granule neurons have transcribed and translated the message for one or more putative "suicide proteins" and that ROS are produced downstream of this protein synthesis. Because the peptide ICE inhibitor required prolonged exposure for cell protection, no such experiment for the kinetics of ICE inhibitors could be performed.

To further elucidate the sequential mechanisms of apoptosis in cerebellar granule neurons, we studied the effects of cycloheximide, Ac-YVAD-CMK, and antioxidants on ICE-like protease activity as measured with the fluorogenic ICE substrate DABCYL-YVADAPV-EDANS. As expected, Ac-YVAD-CMK completely blocked ICE-like activity (Fig. $7 A$ ). In addition, neurons treated with cycloheximide at the time of switching did not exhibit ICE-like activity, suggesting that the putative killer proteins are an upstream positive regulator of ICE-like protease activity. In contrast, PBN, SOD, and $N$-acetyl-L-cysteine did not affect ICE-like protease activity. In another experiment, we studied the effects of cycloheximide, Ac-YVAD-CMK, and PBN on ROS production with the oxidation-sensitive indicators $\mathrm{DCF}-\mathrm{H}_{2}$ and dihydrorhodamine 123 at $4 \mathrm{hr}$ after $\mathrm{K}^{+}$deprivation (Fig. $7 B, C)$. As expected, PBN prevented the increase of DCF and rhodamine 123 fluorescence. However, cycloheximide and AcYVAD-CMK had a similar effect, suggesting that both agents interfere with the apoptotic cascade upstream of ROS formation.

\section{DISCUSSION}

The regulation of programmed cell death in the developing nervous system involves target-derived survival factors, afferent synaptic activity, and hormone- and cytokine-dependent signaling. Cerebellar granule neurons undergo extensive cell death characterized by nuclear DNA fragmentation between postnatal days 5 and 9 (P5 and P9) in vivo (Wood et al., 1993). Mossy fiber input to the granule cell layer begins at P5, and synapse formation occurs by P12 (Burgoyne and Cambray-Deakin, 1988). Similarly, formation of synaptic contacts between parallel fibers and Purkinje cell dendrites is prominent between the second and third postnatal weeks, corresponding to the maximal rate of synaptogenesis (Burgoyne and Cambray-Deakin, 1988). Therefore, cell death before synaptogenesis may help to regulate granule neuron number.

In the absence of exogenously added growth or survival factors other than those present in fetal calf serum, cerebellar granule neurons can be differentiated and maintained in vitro for weeks in the presence of high concentrations of $\mathrm{K}^{+}$. These neurons undergo highly synchronous apoptosis when deprived of depolarizing concentrations of $\mathrm{K}^{+}$(D'Mello et al., 1993; Yan et al., 1994; Galli et al., 1995). We have previously suggested that the functional innervation of postmigratory granule neurons during cerebellar development by mossy fibers and climbing fibers may prevent further elimination of these neurons by blocking their programmed death (Yan et al., 1994). Therefore, $\mathrm{K}^{+}$deprivationinduced apoptosis of differentiated cerebellar granule neurons may be a model of neuronal death after deafferentation. On the other hand, studies that examined the postnatal histogenesis of the cerebellum in normal mice, neurologically mutant mice, and chimeras between normal and mutant mice show that there is a numerical matching of granule neurons with Purkinje cells. They indicate that a target-related cell death of granule cells occurs during development of the cerebellum. The survival-promoting effects of $\mathrm{K}^{+}$in cortical neurons are mediated by a specific neurotrophin, brain-derived neurotrophic factor (Ghosh et al., 1994), suggesting that $\mathrm{K}^{+}$deprivation-induced apoptosis of cerebellar granule neurons may also involve specific unidentified growth factors.

A requirement for new mRNA and protein synthesis is a typical feature of neuronal apoptosis (Johnson and Deckwerth, 1993). Apoptosis of several non-neuronal cells, including lymphoid cells 

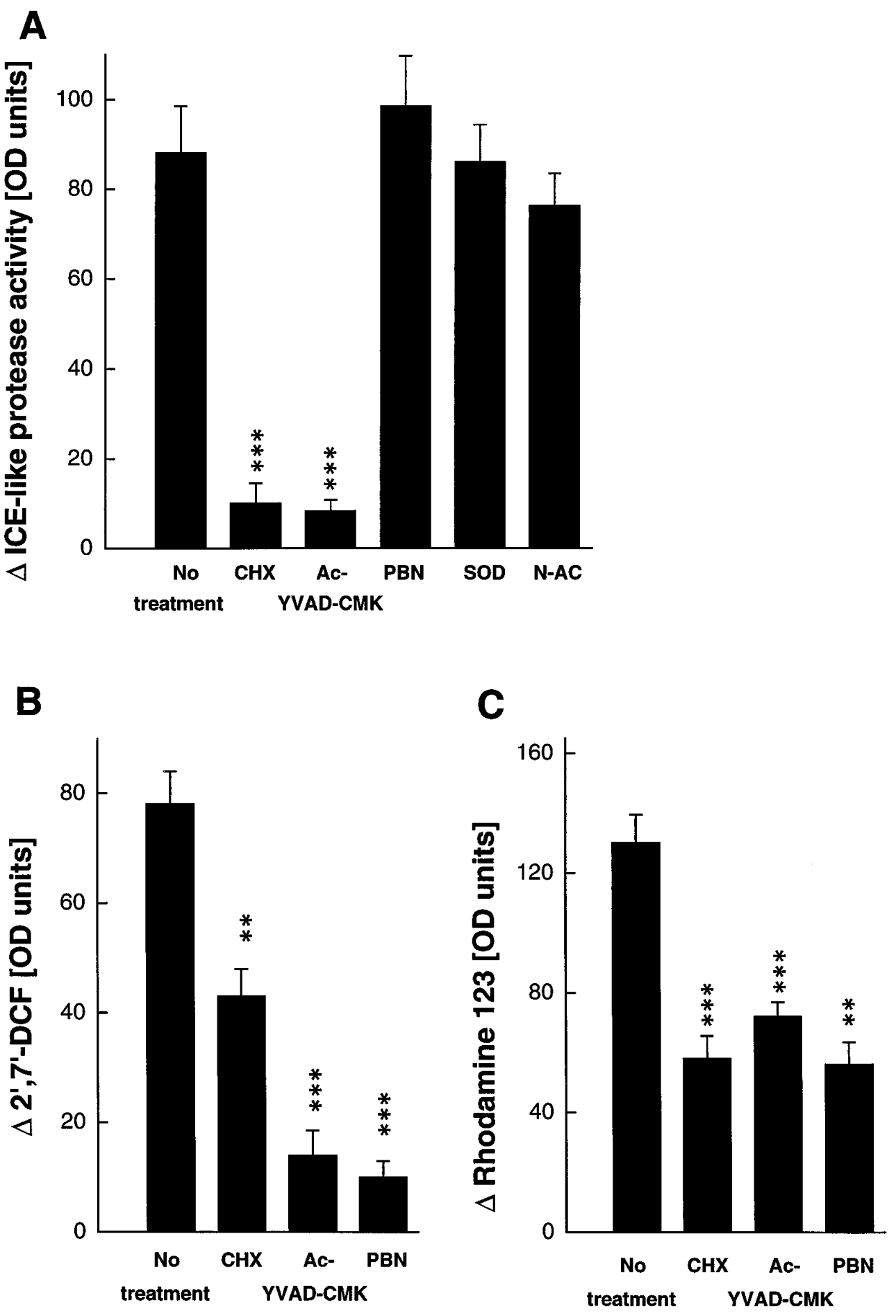

Figure 7. Interaction of RNA translation, induction of ICE-like protease activity, and formation of ROS. $A$, Cycloheximide $(C H X)$ and $A c-Y V A D-C M K$, but not $P B N, S O D$, or $N$-acetyl-Lcysteine $(N-A C)$ prevent the induction of ICE-like activity as measured with the ICE-substrate DABCYL-YVADAPVEDANS at $3 \mathrm{hr}$ after $\mathrm{K}^{+}$deprivation. Cycloheximide (CHX), Ac-YVAD-CMK, and $P B N$ attenuate the production of ROS as detected by $2^{\prime}, 7^{\prime}$-DCF $(B)$ and rhodamine $123(C)$ fluorescence at $4 \mathrm{hr}$ after switch to low $\mathrm{K}^{+}$medium. ${ }^{* *} p<$ $0.01,{ }^{* * *} p<0.001$ compared with untreated granule neurons switched to low $\mathrm{K}^{+}$medium.

and neoplastic cells, in contrast, is induced or augmented by inhibitors of mRNA and protein synthesis (Weller et al., 1994a,b). Here we report that new mRNA and protein synthesis, ICE-like proteases, and production of ROS are necessary and sequential events of apoptosis in this paradigm of neuronal apoptosis. Timekinetic studies revealed that gene activation required for apoptosis is an early event, because exposure to actinomycin D and cycloheximide $>60$ min after $\mathrm{K}^{+}$withdrawal failed to enhance neuronal survival when assessed at $24 \mathrm{hr}$. This is in contrast to nerve growth factor (NGF) deprivation-induced apoptosis of sympathetic neurons, $50 \%$ of which are rescued when protein synthe- sis was blocked within $22 \mathrm{hr}$ of NGF deprivation (Martin et al., 1992).

ICE-like proteases have recently been identified as important mediators of apoptotic cell death, e.g., in Fas/APO-1-mediated apoptosis (Enari et al., 1995; Kuida et al., 1995; Los et al., 1995) and programmed cell death of motor neurons (Milligan et al., 1995). The detection of ICE-like activity by a substrate peptide and the protective effects of an inhibitor of ICE-like proteases strongly suggest that a member of the ICE family of proteases is also involved in $\mathrm{K}^{+}$deprivation-induced apoptosis of cerebellar granule neurons. Treatment with other chloromethylketone inhib- 
itors of proteases (TPCK and TLCK) that lack aspartate in the P1 position and with other protease inhibitors did not result in enhanced neuronal survival. We believe that ICE-like protease activity operates downstream of the putative killer genes because the induction of enzymatic activity was blocked by cycloheximide.

The fluorogenic ICE substrate DABCYL-YVADAPV/EDANS and the peptide ICE inhibitor Ac-YVAD-CMK do not differentiate between members of the ICE family (Lazebnik et al., 1994; Nicholson et al., 1995; Tewari et al., 1995). To examine whether ICE or other ICE-like proteases mediate $\mathrm{K}^{+}$deprivation-induced apoptosis, we studied the role of ICE by Western blotting. Mammalian ICE is synthesized as an inactive $45 \mathrm{kDa}$ precursor processed proteolytically to generate active enzyme that comprises polypeptides of $20 \mathrm{kDa}(\mathrm{p} 20)$ and $10 \mathrm{kDa}(\mathrm{p} 10)$ (Thornberry et al., 1992). We detected the expression of the $45 \mathrm{kDa}$ precursor protein in cerebellar granule neurons but did not observe a 10 $\mathrm{kDa}$ protein or a decrease of the precursor protein up to $8 \mathrm{hr}$ after $\mathrm{K}^{+}$deprivation, indicating that the precursor protein is not cleaved to the active ICE subunits. The p10 antibody we used was directed against the mouse p10 subunit. The mouse and rat p10 subunits show 95\% homology (Keane et al., 1995). The detection of the $45 \mathrm{kDa}$ precursor protein appears to prove that the antibody detects rat ICE. In contrast, the p10 subunits of other members of the ICE-like protease family show less homology (Kumar, 1995). Our results suggest that not ICE itself, but one or more other members of the ICE family are important regulators of apoptosis in cerebellar granule neurons.

ROS have been implicated as mediators of excitotoxic (Coyle and Puttfarcken, 1993; Schulz et al., 1995a,b) and apoptotic (Hockenbery et al., 1993; Kane et al., 1993; Greenlund et al., 1995; Rabizadeh et al., 1995) neuronal cell death. One major aim of this study was to examine the role of ROS in $\mathrm{K}^{+}$deprivationinduced apoptosis of cerebellar granule neurons. Using redoxsensitive dyes, we found that ROS are generated during apoptosis and that inhibitors of ROS formation prevented neuronal death. Scavengers of superoxide (SOD, PBN) were equally effective as scavengers of peroxides (glutathione, catalase), antioxidants (vitamin E), and $N$-acetyl-L-cysteine, a thiol antioxidant and glutathione precursor. These pharmacological data indicate that superoxide, hydrogen peroxide, and hydroxyl radicals are produced in $\mathrm{K}^{+}$-deprived cerebellar granule neurons. Measurements with the redox-sensitive dyes $\mathrm{DCF}-\mathrm{H}_{2}$ and dihydrorhodamine 123 indicate that there is an increase in the formation of ROS that peaks at 4 $\mathrm{hr}$ and slowly declines thereafter. The time course of the production of free radicals correlates well with the ability of PBN to protect against apoptosis. ROS formation is a downstream event in granule neuron apoptosis because both cycloheximide and the ICE inhibitor prevented ROS formation.

The antiapoptotic properties of the $b c l-2$ oncogene product have been attributed to the detoxification of ROS (Hockenbery et al., 1993). Although cerebellar granule neurons maintained in high $\mathrm{K}^{+}$medium express $b c l-2$ mRNA (Montpied et al., 1993), we have not been able to detect the BCL-2 protein in cerebellar granule neurons maintained in either high $\mathrm{K}^{+}$or low $\mathrm{K}^{+}$medium (de Luca et al., 1996). Thus, cerebellar granule neurons may be specifically vulnerable to ROS-induced toxicity.

ROS formation is a downstream event in the intracellular cascade leading to apoptosis of cerebellar granule neurons. We show that gene induction and activation of ICE-like proteases are necessary for the generation of ROS. The mechanism of ROSinduced cytotoxicity is unclear. Targets of cell injury by ROS are cellular macromolecules including DNA. ROS-mediated DNA damage is unlikely to be responsible for cell death because p53 activity was not induced and because antioxidants and inhibitors of ICE-like proteases inhibited cell death but not DNA fragmentation. Apoptosis of neuronal precursors in the cerebellum of transgenic mice lacking functional p53 is similar to that in wildtype mice, arguing for a p53-independent apoptotic pathway of physiological cerebellar granule cell loss during development (Wood and Youle, 1995). In contrast, p53 expression is required for gamma irradiation-induced apoptosis of cerebellar granule neuron precursors in vivo.

In contrast to their recognized role as damaging molecules, ROS have recently been implicated as important signal transduction molecules. Sympathetic neurons show an increase in ROS that peaks at $3 \mathrm{hr}$ after deprivation of NGF. If NGF was added back to the culture medium after the period of peak ROS generation, apoptosis was completely prevented, suggesting that ROS production serves as an early signal, rather than a toxic agent, to mediate apoptosis (Greenlund et al., 1995). Commitment to cell death is defined as the time after which readdition of trophic support or other treatment will no longer prevent cell death. Fifty percent of sympathetic neurons can be rescued when protein synthesis was blocked $22 \mathrm{hr}$ after NGF deprivation (Martin et al., 1992). Therefore, it was argued that ROS may signal by modulating transcription either directly or through known redoxsensitive proteins or transcription factors. This cascade is different in $\mathrm{K}^{+}$deprivation-induced apoptosis of cerebellar granule neurons, because (1) neurons can only be rescued after $\mathrm{K}^{+}$deprivation when inhibitors of transcription and translation are added during the first hour (whereas free radical scavengers protect when added up to $3 \mathrm{hr}$ after switch to low $\mathrm{K}^{+}$) and (2) generation of ROS is a downstream event of protein synthesis.

Apoptosis of cerebellar granule neurons induced by $\mathrm{K}^{+}$deprivation is associated with DNA fragmentation that is prevented by inhibition of protein synthesis. However, treatment with the peptide inhibitor of ICE-like proteases, Ac-YVAD-CMK, and a free radical scavenger did not block DNA fragmentation at $24 \mathrm{hr}$ after $\mathrm{K}^{+}$deprivation. Although $90 \%$ of cells were viable at that time point with either treatment, almost $20 \%$ of the total DNA was fragmented. When switched back to conditioned medium, this fragmentation did not lead to further cell death, but DNA appeared to be partially repaired. These results argue against the hypothesis that the degree of DNA fragmentation observed in cerebellar granule neurons will necessarily lead to apoptotic death. The finding that apoptosis can be induced in enucleated cells (cytoblasts) provided evidence that events occurring independently or upstream of nuclear alterations have a major impact in the regulation and execution of apoptosis (Jacobson et al., 1994; Schulze-Osthoff et al., 1994). Our data indicate that DNA fragmentation is an epiphenomenal event in $\mathrm{K}^{+}$deprivationinduced apoptosis of cerebellar granule neurons.

\section{Conclusions}

Previous studies have shown that $\mathrm{K}^{+}$deprivation-induced apoptosis of cerebellar granule neurons requires new mRNA and protein synthesis. Here we present data that provide a framework for the understanding of the apoptotic cascade in these neurons. Our results suggest that an ICE-like protease is a critical mediator of this apoptotic cell death. Although we cannot identify the specific protease of the ICE family involved in apoptosis of cerebellar granule neurons, it is unlikely to be ICE itself. Further, ROS are essential mediators of apoptotic cell death. Because inhibition of transcription, translation, and of ICE-like activity prevents pro- 
duction of ROS, ROS formation is a downstream event in the intracellular cascade leading to apoptotic cell death. The mechanisms by which ROS induce cell death remain to be elucidated.

\section{REFERENCES}

Behl C, Davis JB, Lesley R, Schubert D (1994) Hydrogen peroxide mediates amyloid $\beta$ protein toxicity. Cell 77:817-827.

Bredesen DE (1995) Neural apoptosis. Ann Neurol 38:839-851.

Burgoyne RD, Cambray-Deakin MA (1988) The cellular neurobiology of neuronal development: the cerebellar granule cell. Brain Res Rev 13:77-101.

Clarke AR, Purdie CA, Harrison DJ, Morris RG, Bird CC, Hooper ML, Wyllie AH (1993) Thymocyte apoptosis induced by p53-dependent and independent pathways. Nature 362:849-851.

Coyle JT, Puttfarcken P (1993) Oxidative stress, glutamate and neurodegenerative disorders. Science 262:689-695.

de Luca A, Weller M, Frei K, Fontana A (1996) Maturation-dependent modulation of apoptosis in cultured cerebellar granule neurons by cytokines and neurotrophins. J Neurosci 13:4174-4185.

D'Mello SR, Galli C, Ciotti T, Calissano P (1993) Induction of apoptosis in cerebellar granule neurons by low potassium: inhibition of death by insulin-growth factor I and cAMP. Proc Natl Acad Sci USA 90:10989-10993.

Enari M, Hug H, Nagata S (1995) Involvement of an ICE-like protease in Fas-mediated apoptosis. Nature 375:78-81.

Galli C, Meucci O, Scorziella A, Werge T, Calissano P, Schettini G (1995) Apoptosis in cerebellar granule cells is blocked by high $\mathrm{KCl}$, forskolin, and IGF-1 through distinct mechanisms of action: the involvement of intracellular calcium and RNA synthesis. J Neurosci 15:1172-1179.

Ghosh A, Carnaham J, Greenberg ME (1994) Requirement for BDNF in activity-dependent survival of cortical neurons. Science 263:1618-1622.

Greenlund LJS, Deckwerth TL, Johnson EM (1995) Superoxide dismutase delays neuronal apoptosis: a role for reactive oxygen species in programmed neuronal death. Neuron 14:303-315.

Héron A, Pollard H, Dessi F, Moreau J, Lasbennes F, Ben-Ari Y, Charriaut-Marlangue C (1993) Regional variability in DNA fragmentation after global ischemia evidenced by combined histological and gel electrophoresis observations in the rat brain. $J$ Neurochem 61:1973-1976.

Hockenbery DM, Oltvai ZN, Yin X-M, Milliman CL, Korsmeyer SJ (1993) Bcl-2 functions in an antioxidant pathway to prevent apoptosis. Cell 75:241-251.

Jacobson MD, Burne JF, Raff MC (1994) Programmed cell death and $\mathrm{Bcl}-2$ protection in the absence of a nucleus. EMBO J 13:1899-1910.

Johnson EM, Deckwerth TL (1993) Molecular mechanisms of developmental neuronal death. Annu Rev Neurosci 16:31-46.

Johnson LV, Walsh ML, Chen LB (1980) Localization of mitochondria in living cells with rhodamine 123. Proc Natl Acad Sci USA 77:990-994.

Kane DJ, Sarafian TA, Anton R, Hahn H, Butler Gralla E, Selverstone Valentine J, Örd T, Bredesen DE (1993) Bcl-2 inhibition of neuronal death: decreased generation of reactive oxygen species. Science 262:1274-1277.

Keane K, Giegel D, Lipinski W, Callahan M, Shivers B (1995) Cloning, tissue expression and regulation of rat interleukin $1 \beta$ converting enzyme. Cytokine 7:105-110.

Knecht KT, Mason RP (1993) In vivo spin trapping of xenobiotic free radical metabolites. Arch Biochem Biophys 303:185-194.

Kuida K, Lipke JA, Ku G, Harding MW, Livingston DJ, Su MS-S, A FR (1995) Altered cytokine export and apoptosis in mice deficient in interleukin $1 \beta$ converting enzyme. Science 267:2000-2003.

Kumar S (1995) ICE-like proteases in apoptosis. Trends Biochem Sci 20:198-202.

Kumar S, Kinoshita M, Noda M, Copeland NG, Jenkins NA (1994) Induction of apoptosis by the mouse Nedd 2 gene, which encodes a protein similar to the product of the Caenorhabditis elegans cell death gene ced-3 and the mammalian IL- $1 \beta$-converting enzyme. Genes Dev 8:1613-1626.

Lazebnik YA, Kaufmann SH, Desnoyers S, Poirier GG, Earnshaw WC (1994) Cleavage of poly(ADP-ribose) polymerase by a proteinase with properties like ICE. Nature 371:346-347.

Li Y, Chopp M, Jiang N, Zhang ZG, Zaloga C (1995) Induction of DNA fragmentation after 10 to $120 \mathrm{~min}$ of focal cerebral ischemia in rats. Stroke 26:1252-1258.
Loo DT, Copani A, Pike CJ, Whittemore ER, Walencewicz AJ, Cotman CW (1993) Apoptosis is induced by $\beta$-amyloid in cultured central nervous system neurons. Proc Natl Acad Sci USA 90:7951-7955.

Los M, Van de Craen M, Penning LC, Schenk H, Westendorp M, Baeuerle PA, Dröge W, Krammer PH, Fiers W, Schulze-Osthoff K (1995) Requirement of an ICE-CED-3 protease for Fas/APO-1mediated apoptosis. Nature 375:81-83.

Lowe SW, Ruley HE, Jacks T, Housman DE (1993a) p53-dependent apoptosis modulates the cytotoxicity to anticancer agents. Cell 74:957-967.

Lowe SW, Schmitt EM, Smith SW, Osborne BA, Jacks T (1993b) p53 is required for radiation-induced apoptosis in mouse thymocytes. Nature 362:847-849.

Marini AS, Paul SM (1992) $N$-methyl-D-aspartate receptor mediated neuroprotection in cerebellar granule cells requires new RNA and protein synthesis. Proc Natl Acad Sci USA 89:6555-6559.

Martin DP, Ito A, Horigome K, Lampe PA, Johnson Jr EM (1992) Biochemical characterization of programmed cell death in NGFdeprived sympathetic neurons. J Neurobiol 23:1205-1220.

Milligan CE, Prevette D, Yaginuma H, Homma S, Cardwell C, Fritz LC, Tomaselli KJ, Oppenheim RW, Schwartz LM (1995) Peptide inhibitors of the ICE protease family arrest programmed cell death of motoneurons in vivo and in vitro. Neuron 15:385-393.

Miura M, Zhu H, Rotello R, Hatwieg EA, Yuan J (1993) Induction of apoptosis in fibroblasts by IL- $1 \beta$-converting enzyme, a mammalian homolog of the C. elegans cell death gene ced-3. Cell 75:653-660.

Montpied P, Weller M, Paul SM (1993) $N$-methyl-D-aspartate receptor agonists decrease protooncogene $b c l-2$ mRNA expression in cultured rat cerebellar granule neurons. Biochem Biophys Res Commun 195:623-629.

Nicholson DW, Ali A, Thornberry NA, Vaillancourt JP, Ding CK, Gallant M, Gareau Y, Griffin PR, Labelle M, Lazebnik YA, Munday NA, Raju SM, Smulson ME, Yamin T-T, Yu VL, Miller DK (1995) Identification and inhibition of the ICE/CED-3 protease necessary for mammalian apoptosis. Nature 376:37-43.

Nicoletti F, Wroblewski JT, Novelli A, Alho H, Guidotti A, Costa E (1986) The activation of inositol phospholipid metabolism as a signaltransducing system for excitatory amino acids in primary cultures of cerebellar granule cells. J Neurosci 6:1905-1911.

Novelli A, Reilly JA, Lysko PG, Henneberry RC (1988) Glutamate becomes neurotoxic via the $N$-methyl-D-aspartate receptor when intracellular energy levels are reduced. Brain Res 451:205-212.

Oppenheim RW (1991) Cell death during development of the nervous system. Annu Rev Neurosci 14:453-501.

Pennington MW, Thornberry NA (1994) Synthesis of a fluorogenic interleukin- $1 \beta$ converting enzyme substrate based on resonance transfer. Pept Res 7:72-76.

Portera-Cailliau C, Hedreen JC, Price DL, Koliatsos VE (1995) Evidence for apoptotic cell death in Huntington disease and excitotoxic animal models. J Neurosci 15:3775-3787.

Rabizadeh S, Butler Gralla E, Borchelt DR, Gwinn R, Selverstone Valentine J, Sisodia S, Wong P, Lee M, Hahn H, Bredesen DE (1995) Mutations associated with amyotrophic lateral sclerosis convert superoxide dismutase from an antiapoptotic gene to a proapoptotic gene: studies in yeast and neural cells. Proc Natl Acad Sci USA 92:3024-3028.

Rosenbaum DM, Michaelson M, Batter DK, Doshi P, Kessler JA (1994) Evidence for hypoxia-induced, programmed cell death of cultured neurons. Ann Neurol 36:864-870.

Roy N, Mahadevan MS, McLean M, Shutler G, Yaraghi Z, Farahani R, Baird S, Besner-Johnston A, Lefebre C, Kang X, Salih M, Huguette A, Tamai K, Guan X, Ioannou P, Crawford TO, de Jong PJ, Surth L, Ikeda J-E, Korneluk RG, MacKenzie A (1995) The gene for neuronal apoptosis inhibitory protein is partially deleted in individuals with spinal muscular atrophy. Cell 80:167-178.

Schulz JB, Henshaw DR, Siwek D, Jenkins BG, Ferrante RJ, Cipolloni PB, Kowall NW, Rosen BR, Beal MF (1995a) Involvement of free radicals in excitotoxicity in vivo. J Neurochem 64:2239-2247.

Schulz JB, Matthews RT, Jenkins BG, Ferrante RJ, Siwek D, Henshaw DR, Cipolloni PB, Mecocci P, Kowall NW, Rosen BR, Beal MF (1995b) Blockade of neuronal nitric oxide synthase protects against excitotoxicity in vivo. J Neurosci 15:8419-8429.

Schulze-Osthoff K, Walczak H, Droge W, Krammer PH (1994) Cell nucleus and DNA fragmentation are not required for apoptosis. J Cell Biol 127:15-20. 
Tewari M, Quan LT, O'Rourke K, Desnoyers S, Zeng Z, Beidler DR, Poirier GG, Salvesen GS, Dixit SM (1995) Yama/CPP32b, a mammalian homolog of CED-3, is a CrmA-inhibitable protease that cleaves the death substrate poly(ADP-ribose) polymerase. Cell 81:801-809.

Thornberry NA, Bull HG, Calaycay JR, Chapman KT, Howard AD, Kostura MJ, Miller DK, Molineaux SM, Weidner JR, Aunins J, Elliston KO, Ayala JM, Casano FJ, Chin J, Ding GJ-F, Egger LA, Gaffney EP, Limjuco G, Palyha OC, Raju SM, Rolando AM, Salley JP, Yamin T-T, Lee TD, Shively JE, MacCross M, Mumford RA, Schmidt JA, Tocci MJ (1992) A novel heterodimeric cysteine protease is required for interleukin- $1 \beta$ processing in monocytes. Nature 356:768-774.

Ullrich SJ, Mercer WE, Apella E (1992) Human wild-type p53 adopts a unique conformational and phosphorylation state in vivo during growth arrest of glioblastoma cells. Oncogene 7:1635-1643.

Walker NPC, Talanian RV, Brady KD, Dang LC, Bump NJ, Ferenz CR, Franklin S, Ghayur T, Hackett MC, Hammill LD, Herzog L, Hugunin M, Houy W, Mankovich JA, McGuiness L, Orlewicz E, Paskind M, Pratt CA, Reis P, Summani A, Terranova M, Welch JP, Xiong L, Möller A, Tracey DE, Kamen R, Wong WW (1994) Crystal structure of the cysteine protease interleukin- $1 \beta$-converting enzyme: a $(\mathrm{p} 20 / \mathrm{p} 10)_{2}$ homodimer. Cell 78:343-352.

Wang L, Miura M, Bergeron L, Zhu H, Yuan J (1994) Ich-1, an Ice/ced3 -related gene, encodes both positive and negative regulators of programmed cell death. Cell 78:739-750.

Weller M, Marini AM, Paul SM (1992) Niacinamide blocks 3-acetylpyridine toxicity of cerebellar granule cells in vitro. Brain Res 594:160-164.

Weller M, Constam DB, Malipiero U, Fontana A (1994a) Transforming growth factor- $\beta 2$ induces apoptosis of murine $\mathrm{T}$ cell clones without down-regulating bcl-2 mRNA expression. Eur J Immunol 24:1293-1300.

Weller M, Frei K, Groscurth P, Krammer PH, Yonekawa Y, Fontana A (1994b) Anti-Fas/APO-1 antibody-mediated apoptosis of cultured hu- man glioma cells: induction and modulation of sensitivity by cytokines. J Clin Invest 94:954-964.

Weller M, Montpied P, Paul SM (1994c) NMDA receptor-mediated excitoprotection of cultured cerebellar granule neurons fails to alter glutamate-induced expression of c-fos and c-jun mRNAs. Mol Brain Res 22:227-235.

Weller M, Malipiero U, Aguzzi A, Reed JC, Fontana A (1995) Protooncogene $b c l-2$ gene transfer abrogates Fas/APO-1 antibody-mediated apoptosis of human glioma cells and confers resistance to chemotherapeutic drugs and therapeutic irradiation. J Clin Invest 95:2633-2643.

Wilson KB, Black JF, Thomson JA, Kim E, Griffith JP, Navia MA, Murcko MA, Chambers SP, Aldape RA, Raybuck SA, Livingston DJ (1994) Structure and mechanism of interleukin- $1 \beta$ converting enzyme. Nature 370:270-275.

Wood KA, Youle RJ (1995) The role of free radicals and p53 in neuron apoptosis in vivo. J Neurosci 15:5851-5857.

Wood KA, Dipasquale B, Youle RJ (1993) In situ labeling of granule cells for apoptosis-associated DNA fragmentation reveals different mechanisms of cell loss in developing cerebellum. Neuron 11:621-632.

Yan G-M, Ni B, Weller M, Wood K, Paul SM (1994) Depolarization or glutamate receptor activation blocks apoptotic cell death of cultured cerebellar granule neurons. Brain Res 656:43-51.

Yuan J, Shaham S, Ledoux S, Ellis HM, Horvitz HR (1993) The C. elegans cell death gene ced-3 encodes a protein similar to mammalian interleukin-1 $\beta$-converting enzyme. Cell 75:641-652.

Zamzami N, Marchetti P, Castedo M, Decaudin D, Macho A, Hirsch T, Susin SA, Petit PX, Mignotte B, Kroemer G (1995) Sequential reduction of mitochondrial transmembrane potential and generation of reactive oxygen species in early programmed cell death. J Exp Med 367:367-377. 